\title{
OBSERVASI KLINIK PEMBERIAN AROMA PANDAN WANGI TERHADAP TEKANAN DARAH PASIEN HIPERTENSI
}

\author{
Mukti Priastomo*, Riska Putri Patila Sau, Jaka Fadraersada \\ Laboratorium Penelitian dan Pengembangan Kefarmasian "Farmaka Tropis", \\ Fakultas Farmasi, Universitas Mulawarman, Samarinda, Indonesia. \\ *Email: mukti@ farmasi.unmul.ac.id
}

\begin{abstract}
Pandanus leaves has a distinctive flavor that from essential oils. The essential oil content of pandanus leaves consists of $6-42 \%$ sesquiterpenes hydrocarbons, $6 \%$ monoterpenes of linalool and $10 \%$ aromatic compounds of 2-acetyl-1 pyrroline. Essential oil compounds of pandanus leaves provide a relaxing effect on hypertensive patients. This research aims to determine the characteristics, patterns of treatment and effect of giving aroma from pandanus leaves to blood pressure on hypertensive patients in Puskesmas Sempaja Samarinda. The research method used is experimental quasy. The procedures in this study used the pre - test and the post - test. Characteristic and pattern of treatment data collection was done retrospectively and got the highest percentage of sex is women as much as 55,36\%. Age with the highest percentage was middle age of $57.14 \%$. The most consumed drug is amlodipine as much as $75.45 \%$. The results of the analysis of the giving aroma from pandanus leaves before and after the aroma was decreased at the sistol pressure of $7.5 \mathrm{mmHg}$, at diastol pressure of $1.1 \mathrm{mmHg}$ and decrease in heart rate as much as $3.1 \mathrm{bpm}$. The conclusion of this research is that women suffer more hypertension, the highest age of hypertension is middle age and the most consumed drug is amlodipine. The result of aroma from pandanus leaves can lower blood pressure and heart rate.
\end{abstract}

Keywords : Aroma; Blood Pressure; Characteristic; Heart Rate; Pandanus leaves.

\begin{abstract}
ABSTRAK
Daun pandan wangi memiliki aroma khas yang berasal dari minyak atsiri. Kandungan minyak atsiri pada daun pandan wangi terdiri dari 6-42\% hidrokarbon sesquiterpen dan $6 \%$ monoterpen linalool dan $10 \%$ senyawa aromatik berupa 2-acetyl-1 pyrroline. Senyawa minyak atsiri daun pandan wangi memberikan efek relaksasi pada pasien hipertensi. Penelitian ini bertujuan untuk melihat karakteristik, pola pengobatan dan efek dari pemberian aroma pandan wangi terhadap tekanan darah pasien hipertensi di Puskesmas Sempaja Samarinda. Metode penelitian yang digunakan adalah metode eksperimental quasy. Prosedur dalam penelitian ini menggunakan pengukuran awal dan pengukuran akhir. Pengumpulan data karakteristik dilakukan secara retrospektif dan didapatkan persentase tertinggi dari jenis kelamin adalah perempuan sebanyak 55,36\%. Usia dengan persentase tertinggi adalah usia pertengahan sebanyak $57,14 \%$. Obat yang paling banyak dikonsumsi adalah amlodipin sebanyak $75,45 \%$. Hasil analisis dari pemberian aroma pandan wangi sebelum dan setelah pemberian aroma terjadi penurunan pada tekanan sistol sebanyak 7,5 $\mathrm{mmHg}$, pada tekanan diastol sebanyak $1,1 \mathrm{mmHg}$ dan penurunan pada
\end{abstract}


denyut jantung sebanyak 3,1. Kesimpulan dari penelitian ini adalah perempuan lebih banyak menderita hipertensi, usia yang paling tinggi terkena hipertensi adalah usia pertengahan dan obat yang paling banyak dikonsumsi adalah amlodipin. Hasil dari intervensi aroma dari pandan wangi dapat menurunkan tekanan darah dan denyut jantung.

Kata Kunci: Aroma; Daun pandan wangi; Denyut Jantung; Karakteristik; Tekanan darah

DOI: https://doi.org/10.25026/jsk.v1i10.98

\section{PENDAHULUAN}

Prevalensi

hipertensi di

Kalimantan Timur dari jumlah penduduk 4.115.471 jiwa mencapai $29,6 \%$ yang berarti terdapat 1.218.259 jiwa yang mengalami hipertensi. ${ }^{1} \quad$ Tingginya tingkat prevalensi hipertensi ini maka perlu dilakukan pengendalian tekanan darah untuk mengatasi hipertensi, hal ini dapat dilakukan secara farmakologi dan non farmakologi. Penanganan secara farmakologi dapat diberi obat - obat hipertensi berupa diuretik, betabloker, ACE inhibitor, angiotensin II receptor blocker, antagonis kalsium, vasodilator. ${ }^{2}$ Penanganan secara non farmakologi diantaranya adalah teraapi akupresur (akupuntur tanpa jarum), pengobatan herbal dari cina, terapi jus, pijat, yoga, pengobatan pada pikiran dan tubuh, biofeedback meditasi, dan aromaterapi. ${ }^{3}$

Aromaterapi merupakan salah satu terapi alternatif yang dapat diberikan pada penderita hipertensi karena pemberian aromaterapi dapat memberikan rasa tenang pada pasien hipertensi yang mengalami stress ataupun gejala lain yang terkait stress seperti kecemasan, insomnia, hingga depresi. Aromaterapi berasal dari minyak tumbuhan atau yang biasa dikenal dengan sebutan minyak atsiri. Minyak atsiri merupakan salah satu jenis minyak nabati yang memiliki banyak manfaat. Karakter fisiknya berupa cairan kental yang dapat disimpan pada suhu ruang. Bahan baku minyak ini diperoleh dari berbagai bagian tanaman seperti daun, bunga, buah, biji, kulit biji, batang, akar atau rimpang. Salah satu ciri utama minyak atsiri yaitu mudah menguap dan beraroma khas sesuai tanamannya masing-masing. ${ }^{4}$ Tanaman Pandanus amaryllifolius termasuk famili Pandanaceae, genus Pandanus. Pandan wangi tumbuh di daerah tropis dan merupakan tanaman perdu tahunan dengan tinggi 1-2 m. Khasiat tanaman ini adalah sebagai rempah-rempah, bahan penyedap, pewangi dan pemberi warna hijau pada masakan atau penganan dan bahan baku pembuatan minyak wangi. Selain itu pandan juga digunakan sebagai obat tradisional untuk mencegah rambut rontok, menghitamkan rambut, menghilangkan ketombe, mengobati lemah saraf (neurastenia), tidak nafsu makan, rematik, sakit disertai gelisah dan memberikan rasa relaks. Daun pandan wangi mempunyai kandungan kimia antara lain alkaloida saponin, flavonoida, tanin, polifenol, dan zat warna. Pandan wangi merupakan salah satu tanaman yang potensial untuk menghasilkan minyak atsiri. ${ }^{5}$

Daun pandan yang banyak terdapat di daerah Kalimantan dan sering dimanfaatkan sebagai pengaroma makanan karena aroma khasnya ini belum banyak dilakukan penelitian, sehingga perlu mengetahui potensi dari tanaman ini dalam memberikan efek menenangkan dari aroma khasnya yang dapat mempengaruhi nilai dari tekanan darah seseorang.

\section{METODE PENELITIAN}

Penelitian ini adalah penelitian semi kuantitatif, dimana dalam penelitian ini data yang didapatkan adalah data 
karakteristik dan dilakukan secara retrospektif mulai bulan Januari - Juli 2017 di Puskesmas Sempaja Samarinda dan data hasil pengukuran tekanan darah sebelum dan setelah diberi intervensi aroma daun pandan wangi dilakukan secara prospektif dalam waktu 3 hari berturut-turut. Rancangan penelitian ini adalah penelitian eksperimen semu (quasy experiment). Desain penelitian ini menggunakan one group pre-post test design, dimana dalam penelitian ini tidak menggunakan kelompok pembanding namun menggunakan tes awal sehingga besarnya pengaruh terhadap pemberian aroma pandan wangi dapat diketahui secara pasti. Populasi dalam penelitian ini adalah seluruh pasien hipertensi yang masuk dalam rentang usia pertengahan (45 - 59 tahun) baik laki-laki maupun perempuan dan tidak memiliki penyakit lain (komplikasi penyakit) di Puskesmas Sempaja, Samarinda.

Teknik sampling dalam penelitian ini menggunakan metode purposive sampling. Kriteria inklusi dalam penelitian ini adalah termasuk dalam usia pertengahan $\geq 45$ tahun, dapat berkomunikasi verbal secara aktif dan bersedia menjadi subjek penelitian. Kriteria eksklusi dalam penelitian ini adalah pasien tidak dapat dihubungi dan ditemui dan pasien yang memiliki alergi terhadap bau tanaman atau tidak menyukai bau tanaman. Variabel indenpenden penelitian ini adalah aroma dari daun pandan wangi aroma dari daun pandan wangi dan variabel dependen penelitian ini adalah perubahan tekanan darah pada pasien hipertensi.

Alat yang digunakan dalam penelitian ini adalah alat destilasi yang digunakan untuk mengambil minyak atsiri dari daun pandan, botol vial $15 \mathrm{ml}$, Tensimeter, drop pipet $1 \mathrm{ml}$, handuk, mangkok kaca, gelas ukur 200 ml, lembar pengumpul data (didalamnya berisi No. Responden, usia, jenis kelamin, obat antihipertensi yang dikonsumsi dan observasi awal tekanan darah sebelum pemberian intervensi dan hasil observasi sesudah perlakuan pemberian aroma daun pandan wangi), dan informed consent. Sampel yang digunakan adalah daun pandan segar yang diambil di daerah Berambai Kota Samarinda. Bahan yang digunakan adalah aquades sebagai pelarut saat destilasi dan air panas untuk menguapkan minyak atsiri pada saat pemberian aroma.

\section{HASIL DAN PEMBAHASAN}

Berdasarkan hasil dari penelitian karakteristik di Puskesmas Sempaja Samarinda Januari - Juli Periode 2017, maka dapat dianalisis pada tabel 1 .

Berdasarkan Tabel 1. Didapatkan hasil penelitian dari karakteristik jenis kelamin pasien hipertensi di Puskesmas Sempaja Samarinda jumlah perempuan sebanyak 55,36 \% dan laki - laki 44, $64 \%$.

Perempuan di pertengahan usia 40 tahun keatas akan mengalami fase akhir dari siklus menstruasi atau disebut menopause. Ovarium perempuan pada fase ini akan mengalami penurunan fungsi yang berakibat pada berkurangnya jumlah hormon estrogen dan progesteron yang dihasilkan. ${ }^{6}$

Estradiol yang terdapat dalam estrogen berfungsi untuk menurunkan reseptor AT1 dan angiotensin-converting enzyme (ACE) sehingga mempertahankan Renin Angiotensin Aldosteron System (RAAS) terhadap pengaturan tekanan darah dan munurunkan adanya vasokontriksi. Penurunan hormon estrogen dapat mempengaruhi Renin Angiotensin Aldosteron System (RAAS) yang menyebabkan peningkatan vasokontriksi. 
Tabel 1. Persentase distribusi pasien hipertensi berdasarkan jenis kelamin di Puskesmas Sempaja Samarinda Januari - Juli 2017.

\begin{tabular}{cccc}
\hline No & Jenis Kelamin & Jumlah & Persen (\%) \\
\hline 1. & Laki - Laki & 100 & 44,64 \\
2. & Perempuan & 124 & 55,36 \\
\hline
\end{tabular}

Tabel 2. Persentase distribusi pasien hipertensi berdasarkan usia di Puskesmas Sempaja Samarinda Januari - Juli 2017.

\begin{tabular}{cccc}
\hline No & Usia & Jumlah & Persen $(\%)$ \\
\hline 1. & Usia Pertengahan $(45-59$ th) & 128 & 57,14 \\
2. & Lanjut usia $(60-74$ th) & 85 & 37,9 \\
3. & Lanjut usia tua $(75-90$ th) & 11 & 4,9 \\
\hline
\end{tabular}

Tabel 3. Persentase penggunaan obat anti-hipertensi di Puskesmas Sempaja Samarinda Januari - Juli 2017.

\begin{tabular}{cclc}
\hline No & Obat yang dikonsumsi & Jumlah & Persen $(\%)$ \\
\hline 1 & Amlodipin & 169 & 75,45 \\
2 & Amlodipin dan HCT & 43 & 19,19 \\
3 & Amlodipin dan Kaptopril & 12 & 5,36 \\
\hline
\end{tabular}

Keterangan : HCT = Hidrochlorotiazid

Berdasarkan Tabel 2. didapatkan hasil penelitian dari karakteristik usia pasien lebih banyak yang terkena hipertensi pada lansia kelompok usia pertengahan (45 - 59 tahun). Menurut World Health Organization (WHO) ada beberapa batasan umur Lansia, yaitu usia pertengahan (middle age) adalah 45 - 59 tahun, usia lanjut (fiderly) adalah $60-74$ tahun, lansia tua (old) adalah $75-90$ tahun dan lansia sangat tua (very old) adalah lebih dari 90 tahun.

\section{Umumnya ditemukan}

kecenderungan peningkatan prevalensi menurut peningkatan usia dan biasanya pada usia $\geq 40$ tahun. Hal ini disebabkan karena tekanan arterial yang meningkat sesuai dengan bertambahnya usia, terjadinya regurgitasi aorta, serta adanya proses usia, terjadinya regurgitasi aorta, serta adanya proses degeneratif, yang lebih sering pada usia tua.
Pada saat terjadi penambahan usia sampai mencapai tua, terjadi pula risiko peningkatan penyakit yang meliputi kelainan syaraf/kejiwaan, kelainan jantung dan pembuluh darah serta berkurangnya fungsi panca indera dan kelainan metabolisme pada tubuh. ${ }^{8}$

Berdasarkan Tabel 3 didapatkan hasil penelitian, obat yang paling banyak di konsumsi pasien hipertensi di puskesmas sempaja adalah amlodipin dengan jumlah 169 pasien dengan persentase sebanyak $75,45 \%$.

Menurut (JNC VIII) pengobatan awal yang direkomendasikan untuk hipertensi adalah CCB, ACE-inhibitor, $\mathrm{ARB}$, atau diuretik thiazid dosis rendah untuk pasien yang bukan ras kulit hitam.Amlodipin merupakan obat antihipertensi golongan Calcium - Channel Blockers (CCB). Mekanisme kerja obat golongan Calcium - Channel Blockers 
(CCB) adalah memperlambat pergerakan kalsium ke dalam sel jantung dan dinding arteri (pembuluh darah yang, membawa darah dari jantung ke jaringan) sehingga arteri menjadi relaks dan menurunkan tekanan dan aliran darah di jantung. ${ }^{9}$

Pemilihan terapi CCB lebih diutamakan Pemilihan pemberian terapi CCB lebih diutamakan dari terapi ACE-I disebabkan beberapa faktor pertimbangan yaitu melihat medical record yang telah ada di Puskesmas tersebut bahwa pemberian amlodipin lebih diutamakan serta karena melihat faktor kemudahan konsumsi yaitu $1 \times 24$ jam yang diharapkan dapat meningkatkan kepatuhan pasien. Pemilihan terapi ini juga dapat dilihat dari respon penderita terhadap pengobatan yang sangat tergantung pada usia penderita, probabilitas ini merefleksikan peran dominan dari sistem renin terhadap blood pressure regulation. Pada pasien usia muda konsentrasi renin relatif lebih tinggi dan sangat responsif terdapat pengobatan untuk menekan sistem renin seperti ACEI. Pada pasien lansia konsentrasi renin relatif rendah dan sangat responsif terhadap pengobatan dengan $\mathrm{CCB}$, hal ini dapat menjadi salah satu dasar yang menunjukkan mayoritas penggunaan obat antihipertrensi CCB pada penelitian ini dengan mayoritas penderita berusia lansia. ${ }^{1}$
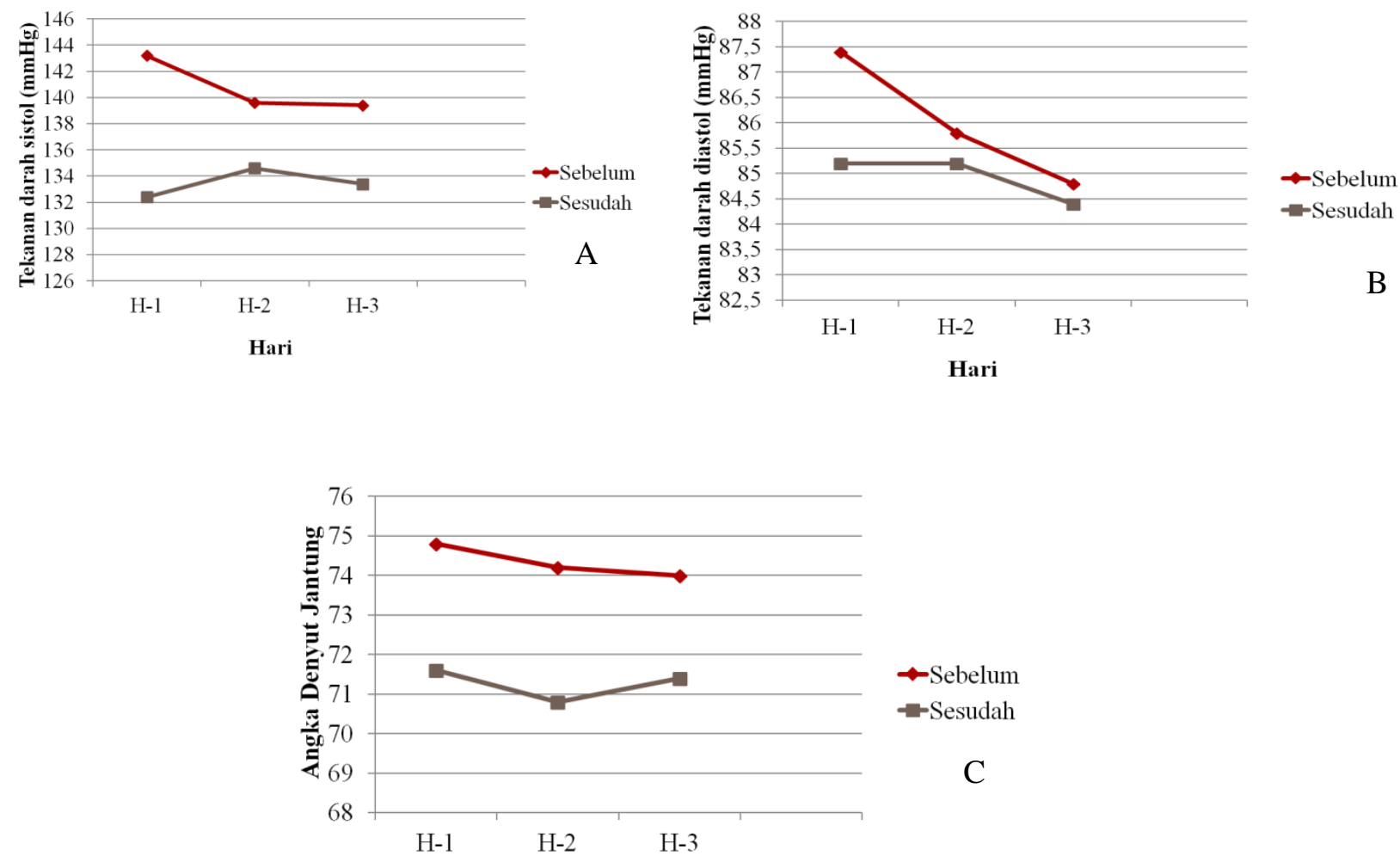

Gambar 1. Gambaran tekanan darah sistol, diastole, dan denyut jantung pasien yang mendapatkan intervensi aroma pandan wangi

Berdasarkan Gambar 1 pada penelitian ini tekanan darah sistol sebelum diberikan aroma daun pandan wangi pada hari- $1=143,9 \mathrm{mmHg}$, hari-2
$=139,6 \mathrm{mmHg}$, dan pada hari-3 = 139,4 $\mathrm{mmHg}$. Nilai rata- rata tekanan darah sistol sebelum diberikan intervensi aroma daun pandan wangi adalah 140,9 $\mathrm{mmHg}$. 
Hasil tekanan darah sistol setelah diberi intervensi adalah pada hari-1 $=132,4$ $\mathrm{mmHg}$, pada hari-2 $=134,6 \mathrm{mmHg}$ dan pada hari-3 $=133,4 \mathrm{mmHg}$. Nilai ratarata tekanan darah sistol setelah diberi intervensi adalah 133,4 mmHg. Terjadi penurunan pada tekanan darah sistol dari sebelum pemberian dan setelah pemberian intervensi sebanyak 7,5 mmHg.

Sementara tekanan darah diastol sebelum diberikan aroma daun pandan wangi pada hari- $1=87,4 \mathrm{mmHg}$, hari- $2=$ $85,8 \mathrm{mmHg}$, dan pada hari-3 $=84,8$ $\mathrm{mmHg}$. Nilai rata- rata tekanan darah sistol sebelum diberikan intervensi aroma daun pandan wangi adalah $86 \mathrm{mmHg}$. Hasil tekanan darah diastol setelah diberi intervensi adalah pada hari-1 $=85,2$ mmHg, pada hari- $2=85,2 \mathrm{mmHg}$ dan pada hari-3 $=84,4 \mathrm{mmHg}$. Nilai rata-rata tekanan darah sistol setelah diberi intervensi adalah 84,9 $\mathrm{mmHg}$. Terjadi penurunan pada tekanan darah diastol dari sebelum pemberian dan setelah pemberian intervensi sebanyak 1,1 $\mathrm{mmHg}$.

Angka denyut jantung sebelum diberikan aroma daun pandan wangi pada hari-1 $=74,8$, hari-2 $=74,2$, dan pada hari-3 $=74$. Nilai rata- rata angka denyut jantung sebelum diberikan intervensi aroma daun pandan wangi adalah 74,3. Hasil angka denyut jantung setelah diberi intervensi adalah pada hari-1 $=71,6$, pada hari-2 $=70,8$ dan pada hari-3 $=$ 71,4 . Nilai rata-rata angka denyut jantung setelah diberi intervensi adalah 71,2. Terjadi penurunan angka denyut jantung sebanyak 3,1 .

Daun pandan wangi secara empiris digunakan sebagai tonikum, penambah nafsu makan, pewangi dan penenang. ${ }^{11}$ Daun pandan wangi mempunyai kandungan kimia antara lain minyak atsiri, alkaloida, saponin, flavonoida, tanin, polifenol, dan zat warna. ${ }^{12}$ Kandungan minyak atsiri pada daun pandan wangi terdiri dari $6-42 \%$ hidrokarbon sesquiterpen dan $6 \%$ monoterpen linalool dan $10 \%$ senyawa aromatik berupa 2 -acetyl-1 pyrroline. ${ }^{13}$ Hasil penelitian menunjukan adanya penurunan terhadap nilai tekanan darah sistol, diastol dan denyut jantung setelah diberi intervensi aroma daun pandan wangi. Hal ini dikarenakan pada kandungan minyak atsiri daun pandan wangi terdapat senyawa linalool, dimana senyawa ini juga terdapat pada tanaman lavender yang telah ditelili bahwa pemberian aroma lavender yang mengandung linalool selama 5 menit dapat memberikan rasa nyaman, rileks dan memperlambat detak jantung. ${ }^{14}$

Sementara senyawa aromatik 2acetyl-1 pyrroline memberikan aroma khas makanan yang menyenangkan yang dapat meningkatkan nafsu makan dan memberikan rasa rileks. ${ }^{15}$ Bahan- bahan aromatik yang terdapat pada minyak atsiri tanaman daun pandan akan merangsang sistem saraf otonom. Sistem ini mengontrol gerakan involunter sistem pernapasan. Neuron-neuron yang bertanggung jawab untuk penciuman adalah sel olfaktori yang melapisi epitel olfaktori pada bagian belakang saluran hidung. Reseptor ini akan menerima saat aroma daun pandan wangi yang mengandung kandungan minyak atsiri tersebut di hirup. Pesan aroma tersebut akan dikirim ke otak yang akan meneruskan pesan ke thalamus untuk mengidentifikasi aroma. Bau akan diinterpretasikan oleh berbagai sel neuron dan dihantarkan ke sistem limbik dan hypothalamus untuk diolah dalam bentuk impuls listrik. Sistem limbik memiliki dua bagian yaitu hipokampus (tempat pengenalan dan memori terhadap bau) serta amigdala tempat yang menjadi pusat kontrol emosi sehingga dapat memperbaiki suasana hati (mood) dan meningkatkan gelombang alfa dalam otak yang memicu pengeluaran hormon serotonin dan endorfin. Pengaturan ini akan membuat rileks dan bau yang menyenangkan akan menstimulasi talamus untuk mengeluarkan enkefalin 
yang merupakan pemberi efek menenangkan ${ }^{16}$.

\section{KESIMPULAN}

1. Hasil dari data karakteristik menunjukkan bahwa di puskesmas Sempaja Samarinda, perempuan lebih banyak menderita hipertensi dengan persentase $55,36 \%$ dan usia yang paling tinggi terkena hipertensi adalah usia pertengahan (45-59 tahun) dengan persentase $57,14 \%$.

2. Hasil dari pola pengobatan obat yang paling banyak dikonsumsi di puskesmas sempaja samarinda adalah amlodipin dengan persentase $75,45 \%$.

3. Hasil dari pemberian aroma daun pandan wangi terhadap pasien hipertensi terjadi penurunan pada tekanan sistol sebanyak 7,5 $\mathrm{mmHg}$, diastol sebanyak $1,1 \mathrm{mmHg}$ dan denyut jantung sebanyak 3,1 .

\section{DAFTAR PUSTAKA}

1. Riset Kesehatan Dasar. 2013. Hipertensi. Jakarta: Badan Penelitian dan Pengembangan Kesehatan, Departemen Kesehatan, Republik Indonesia.

2. Rusdi, Nurlaela Isnawati. 2009. Awas Anda Bisa Mati Cepat Akibat Hipertensi dan Diabetes. Yogyakarta: Powerbooks publishing.

3. Ritu Jain. 2011. Pengobatan Alternatif untuk Mengatasi Tekanan Darah. Jakarta: Gramedia.

4. Walsh, M. E., Debra, R., Tisha, J. 2011. Integrating Complementary and Alternative Medicine: Use of Essentials Oils in Hypertension Management. Journal of Vascular Nursing Volume 29 No. 2 .

5. Rohmawati E. 1995. Skrining Kandungan Kimia Daun Pandan serta Isolasi dan Identifikasi Alkaloidnya. Yogyakarta: Fakultas Farmasi, Universitas Gajah Mada.

6. Manurung, Nixson., Rostinah Manurung., dan Magdhalena Christin T. Bolon. 2017. Asuhan
Keperawatan Sistem Endokrin Dilengkapi Mind Mapping dan Asuhan Keperawatan Nanda Nic Noc. Yogyakarta : Deepublish.

7. Gallagher PE, Li P, Lenhart JR, Chappell MC, Brosnihan KB. 1999. Estrogen regulation of angiotensinconverting enzyme mRNA. Hypertension. [PubMed: 9931124]

8. Anggara, F. H. D., dan Prayitno, N., 2013. Faktor-Faktor Yang Berhubungan Dengan Tekanan Darah Di Puskesmas Telaga Murni, Cikarang Barat Tahun 2012. Jurnal Ilmiah Kesehatan. 5. (1). 20-25.

9. Sweetman, Sean C., Paul S, Blake., Alison, Brayfielf., Julie M, McGlashman, dan Gail C, Neathercoat. 2009. Martindale: The Complete Drug Reference. Great Britai: Pharmaceutical Press.

10. Budisetio, M., 2001. Pencegahan dan Pengobatan Hipertensi pada Penderita Usia

Dewasa. Jurnal Kedokteran Trisakti. 20. (2).

11. Dalimartha, S. 2009. Atlas Tumbuhan Obat Indonesia Jilid 1. Jakarta: Trubus Agriwidya.

12. Buchbauer, Gerhard and Kemal Hüsnü Can Başer. 2010. Handbook of essential Oils: Science, Technology, and Applications. Francis: CRC Press/Taylor \& Francis.

13. Harbone JB. 1987. Metode Fitokimia Penentuan cara Modern Menganalisa Tumbuhan (Penerjemah: Kosasih, P.). Bandung: Terbitan Kedua ITB.

14. Anastasia, Sarah., Bayhakki., dan N. Fathra.,A. 2015. Pengaruh Aromaterapi Inhalasi Lavender Terhadap Kecemasan Pasien Gagal Ginjal Kronik Yang Menjalani Hemodialisis. JOM Universitas Riau. 20. (2).

15. Cheetangdee,V.,Siree,C. 2006. Free Amino Acid and Reducing 
Observasi Klinik Pemberian Aroma Pandan Wangi Terhadap Tekanan Darah Pasien Hipertensi

Sugar Composition of Pandan (Pandanus amaryllifolius Roxb. Leaves. Thailand: Departement of Food Science and
Technology, Faculty of AgroIndustry. Kasetsart University.

16. Sharma, S. 2009. Aromaterapi. Tangerang: Karisma. 